\title{
IMPLEMENTATION OF GUIDED INQUIRY LEARNING MODEL THROUGH CONTEXTUAL APPROACH TO IMPROVE THE ACTIVITY AND STUDY RESULT
}

\author{
Andi Lilis Suryani T., ${ }^{1)}$ Hasri, ${ }^{2)}$ Sugiarti \\ 1) Mahasiswa Pendidikan Kimia ICP FMIPA Universitas Negeri Makassar, Jalan Daeng \\ Tata Makassar, Kampus UNM Parangtambung 90244 \\ Email: suryaaniililist@gmail.com
}

2) Jurusan Kimia FMIPA Universitas Negeri Makassar, Jalan Daeng Tata Makassar, Kampus UNM Parangtambung 90244

\begin{abstract}
This Classroom Action Research (CAR) aimed to know how to implement the steps of Guided Inquiry learning Model through Contextual Approach to improve the activity and study results of the Student of Class XI IPA 3 of SMAN 7 Pinrang. This research was held by two cycles. Research result data show the average percentage of student learning activities the first cycle were $46.80 \%$ in less active category and the second cycle were $69.28 \%$ in active category andcompleteness class percentage the first cycle were $33.33 \%$ not complete category and the second cycle were $83.33 \%$ with complete category. It can conclude that the steps of guided inquiry learning model through contextual approach can be improve the activity and study result of SMAN 7 Pinrang student.
\end{abstract}

Keyword: guided inquiry, contextual approach, learning activity, study result reaction rate.

\section{PENDAHULUAN}

Serangkaian komponen pembelajaran diperankan oleh guru dalam membelajarkan siswa. Guru merupakan faktor penentu yang sangat dominan dalam pendidikan, karena guru memegang peranan penting dalam proses pembelajaran [1]. Jadi, keberhasilan suatu proses pembelajaran sangat bergantung pada kinerja guru. Kinerja guru dipengaruhi oleh kompetensi yang dimilikinya. Salah satunya adalah kompetensi pedagogik yang menekankan pada kemampuan guru dalam mengelolah kegiatan pembelajaran di kelas. Sebagai pengelolah pembelajaran (learning manajer), guru berperan dalam menciptakan iklim belajar yang memungkinkan siswa dapat belajar secara nyaman. Melalui pengelolaan kelas yang baik, guru dapat menjaga kelas agar tetap kondusif sehingga dalam proses belajar seluruh siswa terlibat aktif [2]. Keaktifan siswa dalam pembelajaran dapat dilihat dari segi aktivitasnya.
Siswa SMAN 7 Pinrang banyak menorehkan prestasi di bidang akademik khususnya pada pelajaran kimia. Meskipun demikian, masih terdapat masalah dalam proses pembelajaran di kelas yang menyebabkan pembelajaran belum optimal. Hasil pengamatan peneliti selama proses pembelajaran berlangsung bahwa sebagian besar siswa kelas XI $\mathrm{IPA}_{3}$ kurang aktif, terutama pada saat guru menjelaskan di papan tulis. Siswa lebih banyak mendengar dan mencatat bahkan tidak sedikit pula dari mereka yang melakukan aktivitas lain. Siswa kurang berlatih menemukan sendiri konsep dari materi yang diajarkan. Sehingga ketika diberikan pertanyaan atau soal, siswa terlihat kebingungan. Hal ini berdampak pada hasil belajarnya, misalnya pada nilai hasil ulangan tengah semester ganjil tahun ajaran 2016/2017 menunjukkan bahwa dari tiga kelas XI IPA di SMAN 7 Pinrang, dua kelas diantaranya memiliki persentase nilai 
yang mencapai nilai KKM di atas 50\% sedangkan satu kelas lainnya yang mencapai nilai KKM hanya 50\% yaitu siswa kelas XI IPA IP $_{3}$ Oleh karena itu, guru harus berupaya melibatkan siswa agar aktif dalam pembelajaran. Aktivitas belajar merupakan serangkaian kegiatan pembelajaran yang dilakukan siswa selama proses pembelajaran [3].

Belajar bukan hanya sekedar kegiatan menghafal sejumlah fakta atau informasi. Tetapi belajar adalah berbuat, memperoleh pengalaman tertentu sesuai dengan tujuan yang diharapkan. Karena itu, model pembelajaran harus dapat mendorong aktivitas siswa. Aktivitas atau kegiatan belajar terdiri atas kegiatankegiatan visual, oral, mendengar, menulis. Menggambar, metrik, mental dan emosional. Penelitian ini hanya mengamati empat dari delapan jenis aktivitas belajar diantaranya: akivitas visual, aktivitas oral, aktivitas mendengar dan aktivitas melihat.

$$
\text { Hasil belajar merupakan }
$$

kemampuan-kemampuan yang dimiliki oleh siswa setelah menerima pengalaman belajarnya. Benyamin Bloom membagi hasil belajar menjadi tiga ranah, yaitu ranah kognitif, ranah afektif, dan ranah psikomotorik. Jenis hasil belajar yang dijadikan sebagai instrumen untuk menerapkan langkah-langkah model inkuiri terbimbing berpendekatan kontekstual adalah hasil belajar kognitif.

Pokok bahasan laju reaksi merupakan salah satu materi yang diajarkan di kelas XI SMA. Laju reaksi bukanlah materi yang rumit hanya saja dibutuhkan pemahaman untuk membentuk konsep-konsep dalam materi ini terutama pada konsep perhitungan. Siswa hanya kurang berinisiatif untuk melakukan atau mencoba sendiri mencari dan menemukan konsep materi tersebut kemudian menganggap rumit.

Upaya dilakukan adalah melakukan penelitian tindakan kelas (PTK). Melalui penelitian ini, kita dapat menyaksikan, merasakan, mencermati, dan menghayati mengenai efektif atau tidak efektif pembelajaran yang dilakukan selama inikemudian memperbaiki kekurangankekurangan yang terdapat dalam pembelajaran dengan mengubah, mengembangkan dan meningkatkan gaya mengajar [4]. Salah satu model dan pendekatan pembelajaran yang peneliti terapkan adalah model inkuiri terbimbing berpendekatan kontekstual.

Model pembelajaran inkuiri adalah suatu model pembelajaran yang menekankan pada proses berpikir secara kritis dan analitis untuk mencari dan menemukan sendiri jawaban dari suatu masalah yang dipertanyakan. Model inkuiri terbimbing umumnya diterapkan bagi siswa yang belum memiliki pengalaman berinkuiri. Model ini memiliki beberapa keunggulan yaitu: 1) Proses pembelajaran menjadi berpusat pada siswa, 2) membangun konsep-diri siswa, 3) tingkat harapan siswa bertambah, 4) mengembangkan bakat dan kecakapan individu, 5) menghindarkan siswa dari cara belajar menghafal serta mengembangkan kemampuan penalaran siswa dan mempunyai efek transfer yang lebih baik.

Pendekatan kontekstual (Contextual Teaching and Learning atau CTL) adalah pendekatan pembelajaran yang menekankan kepada proses keterlibatan siswa secara penuh untuk dapat menemukan materi yang dipelajari dan menghubungkannya dengan situasi kehidupan nyata sehingga mendorong siswa untuk dapat menerapkannya dalam kehidupan sehari-hari [2]. Pendekatan ini memiliki tujuh azas yaitu konstruktivisme, menemukan, bertanya, masyarakat belajar, pemodelan dan refleksi. Pendekatan kontekstual dan model inkuiri terbimbing cocok diterapkan pada materi laju reaksi.

Pernyataan tersebut didukung oleh penelitian yang menyatakan bahwa penerapan model pembelajaran inkuiri terbimbing pada pokok bahasan kalor dapat melatih keterampilan proses sains dan meningkatkan hasil belajar siswa $\mathrm{X}_{6}$ SMAN 1 Sumenep [5]. Serta adanya peningkatan hasil belajar siswa SMA Negeri 1 Gorontalo dengan menerapkan pendekatan pembelajaran kontekstual pada materi laju reaksi [6].

Berdasarkan uraian latar belakang tersebut, sehingga penulis termotivasi 
untuk melakukan penelitian tindakan kelas dengan judul" Penerapan model pembelajaran lnkuiri terbimbing berpendekatankontekstualuntuk

meningkatkan aktivitas dan hasil belajar siswa pada materi pokok laju reaksi”.

\section{METODE PENELITIAN}

Penelitian ini merupakan penelitian tindakan kelas (PTK) atau Classroom Action Research (CAR) dengan subjek penelitian adalah siswa kelas XI IPA SMAN 7 Pinrang tahun ajaran 2016/2017 yang berjumlah 30 siswa yang terdiri dari 14 siswa laki-laki dan 16 siswa perempuan.Penelitian ini dilaksanakan selama 7 kali pertemuan (4 minggu) yaitu pada bulan Oktober-November 2016.Desain penelitian ini adalah penelitian tindakan kelas model siklus yang terdiri atas empat tahapan yaitu perencanaan, pelaksanaan, observasi, dan refleksi.

\section{Siklus 1}

\section{Tahap Perencanaan}

a. Mengumpulkan informasi awal mengenai masalah yang dihadapi siswa pada pelajaran kimia.

b. Mengunjungi sekolah (lokasi penelitian).

c. Melakukan wawancara kepada beberapa guru bidang studi kimia mengenai hasil belajar siswasiswanya.

d. Mengamati proses berlangsungnya pelajaran kimia.

e. Melakukan konsultasi kepada guru bidang studi kimia mengenai subjek, waktu, dan materi penelitian.

f. Pertemuan awal dengan siswa sebelumproses pembelajaran.

g. Membuat perangkat pembelajaran.

\section{Tahap pelaksanaan}

a. Melaksanakan pembelajaran berdasarkan rencana pelaksanaan pembelajaran (RPP).

b. Mengisi lembar observasi aktivitas siswa, keterlaksanaan pembelajaran oleh observer.

c. Mengamati aktivitas siswa selama proses pembelajaran.

\section{Tahap pengamatan /observasi}

a.Proses observasi dilakukan oleh dua orang observer.

b.Mengevaluasi siswa dengan materimateri yang telah diajarkan.

c. Observer juga memberikan catatan berupa hambatan dan saran kepada peneliti.

d.Menganalisis data hasil observasi dan tes evaluasi siswa.

\section{Tahap Refleksi}

Refleksi dilaksanakan setelah tahap pada siklus I selesai di mana hasil yang diperoleh dari tahap observasi dijadikan acuan untuk merencanakan tindakan pada siklus berikutnya.

\section{Teknik Pengumpulan Data}

Adapun teknik pengumpulan dalam penelitian ini menggunakan lembar observasi terdiri dari aktivitas belajar siswa, keterlaksanaan pembelajaran, tes hasil belajar berupa tes subjektif (essay) dan catatan lapangan.

\section{Teknik Analisis Data}

Adapun tekhnik analisis data yang digunakan terdiri dari:

1.Lembar observasi aktivitas belajar

2.Lembar observasi keterlaksanaan pembelajaran

3. Tes

4. Catatan lapangan

\section{Indikator Keberhasilan}

Penelitian ini dikatakan berhasil dan siklus pembelajaran dihentikan apabila terjadi peningkatan aktivitas belajar siswa dibandingkan dengan siklus sebelumnya. Tingkat keberhasilan aktivitas belajar ditinjau dari persentase aktivitas belajar minimal telah mencapai kategori aktif $(\geq$ $65 \%$ ).

\section{HASIL DAN PEMBAHASAN}

Penelitian ini berlangsung selama dua siklus di mana siklus I dilaksanakan tiga kali pertemuan untuk tindakan dan satu kali pertemuan untuk tes akhir siklus I sedangkan siklus II dilaksanakan dua kali pertemuan untuk tindakan dan satu kali pertemuan untuk tes akhir siklus II. 


\section{Data Hasil Observasi}

a. Aktivitas belajar Siklus I

Persentase rata-rata aktivitas belajar siswa pada siklus 1 yaitu 46, $80 \%$ tergolong kurang dan persentase rata-rata aktivitas belajar siswa berdasarkan indikator keberhasilan pada siklus I yaitu $47.75 \%$ tergolong kurang aktif.

b. Keterlaksanaan Pembelajaran

Analisis data hasil observasi

keterlaksanaan pembelajaran siklus I menunjukkan bahwa nilai rata-rata persentase keterlaksanaan pembelajaran sebesar $88.89 \%$.

c. Hasil belajar

Nilai tertinggi yang diperoleh siswa dari hasil evaluasi siklus I yaitu 84.85 dan nilai terendah yaitu 36.36. Nilai rata-rata hasil belajar siswa pada siklus I yaitu 60.81 dengan kategori kurang.

d. Catatan Lapangan

Pada pertemuan I, II dan III memiliki kekurangan dan kelebihan masing-masing.

e. Refleksi Siklus I

Hasil analisis data bahwa rata-rata aktivitas belajar siswa berdasarkan langkah-langkah model pembelajaran inkuiri terbimbing berpendekatan kontekstual maupun indikator keberhasilan pada siklus I masih tergolong kurang aktif begitupun nilai rata-rata hasil belajar siswa pada siklus I juga dalam kategori kurang sehingga penelitian dilanjutkan ke siklus II.

\section{Siklus II}

\section{Perencanaan}

Kegiatan perencanaan yang dilakukan pada siklus II adalah merevisi rencana pelaksanaan pembelajaran (RPP) berdasarkan hasil refleksi yang dilakukan pada siklus I.

\section{Pelaksanaan dan Pengamatan}

Pada tahap ini dilaksanakan tindakan pada beberapa item aktivitas yang memiliki persentase rendah berdasarkan hasil refleksi. Melaksanakan pembelajaran menggunakan RPP yang telah modifikasi.

\section{Data hasil observasi}

1) Observasi Aktivitas Belajar

Persentase rata-rata siswa yang melakukan aktivitas belajar pada siklus II yaitu $69.28 \%$ dengan predikat aktif.Item aktivitas siswa yang direfleksi diantaranya:

a.Pada siklus I hanya16.11\% siswa yang menjawab pertanyaan yang diajukan oleh guru pada saat penyampaian apersepsi. Sehingga dimotivasioleh guru agar siswa lebih berani mengutarakan pendapatnya. Guru membuat suasana pembelajaran lebih santai, akrab dengan siswa dan menghampiri tempat duduk siswa selama pembelajaran. Setelah memberikan tindakan persentasenya menjadi $31.67 \%$.

b.Pada siklus I hanya $11.11 \%$ siswa yang berani mengacungkan tangan untuk memberikan jawaban atas pertanyaan yang diajukan oleh guru. Sehingga diberikan tindakan dengan menegaskan kepada siswa agar lebih berani mengutarakan pendapatnya baik berupa jawaban, saran dan tanggapan lainnya. Dan mengatakan bahwa di dalam belajar tidak perlu takut jika menjawab salah. Sehingga pada siklus II persentasenya menjadi $26.67 \%$.

c. Pada siklus I hanya $10.00 \%$ siswa yang mengacungkan tangan menyampaikan dugaan sementara. Sehingga diberikan tambahan topik yang bersifat kontekstual pada rumusan masalah supaya siswa lebih tertarik dan mudah menyelesaikannya. Memberikan poin bagi kelompok yang anggotanya berani mengacungkan tangan untuk berhipotesis sehingga siklus II persentasenya menjadi $32.83 \%$.

d. Pada siklus I hanya $35.56 \%$ siswa yang membaca buku paket atau sumber dalam pembelajaran. Sehinggasiswa ditugaskan untuk membawa buku bagi tiap kelompok minimal adatiga buku pelajaran bagi kelompok yang tidak memenuhi mendapat pengurangan poin. Sehingga pada siklus II persentasenya menjadi $61.67 \%$.

e. Pada siklus I hanya $51.67 \%$ siswa yang antusias bekerja sama menyelesaikan kegiatan siswa dalam LKS. Sehingga 
diberikan tindakan dengan menghampiri siswa dalam setiap kelompok untuk mengetahui sejauh mana penyelesaian tugasnya. Sehingga persentasenya menjadi83.33\%.

f. Pada siklus I hanya $18.89 \%$ siswa yang berusaha mencari sumber lain sebagian besar hanya menggunakan LKS. Tindakannya adalah memberikan tugas kepada siswa untuk membawa referensi berupa artikel atau jurnal terkait sub pokok materi yang dipelajari. Sehingga pada siklus II persentasenya menjadi $58.34 \%$ siswa.

g. Pada siklus I hanya $10.00 \%$ siswa dari setiap kelompok yang berani mengacungkan tangan untuk mengerjakan soal. Guru memotivasi siswa agar lebih berani menunjukkan hasil pekerjaanya di papan tulis. Kemudian menjelaskan bagian yang tidak dipahami oleh siswa. Menunjuk mereka secara acak sehingga pada siklus II persentasenya menjadi $35.00 \%$.

h.Pada siklus I hanya $15.55 \%$ siswa yang antusias mencocokkan hipotesisnya dengan sumber atau data yang diperoleh. Tindakan yang dilakukan yaitu menugaskan kepada siswa menulis hipotesis yang benar. Menghampiri setiap kelompok untuk menyuruh siswa menulis hipotesis yang benar jika hipotesis kelompoknya masih terdapat hal yang keliru. Sehingga pada siklus II persentasenya menjadi $71.67 \%$.

i. Pada siklus I hanya7.78\% siswa yang berani mempertahankan hipotesisnya dikarenakan mereka masih ragu-ragu. Tindakan yang dilakukanadalah menyampaikan kepada siswa bahwa tidak perlu ragu-ragu untuk berpendapat. Sehingga pada siklus II persentasenya menjadi $56.67 \%$.

j. Pada siklus I hanya $12.22 \%$ siswa yang mengacungkan tangan untuk menyampaikan kesimpulan materi yang telah dipelajari. Tindakan yang dilakukan adalah memberikan kesempatan kepada siswa untuk menyampaikan kesimpulan materi yang telah dipelajari. Sehingga pada siklus II persentasenya menjadi26.67\%. Grafik yang menampilkan data aktivitas belajar siswa tiap fase pada siklus I dan siklus II.

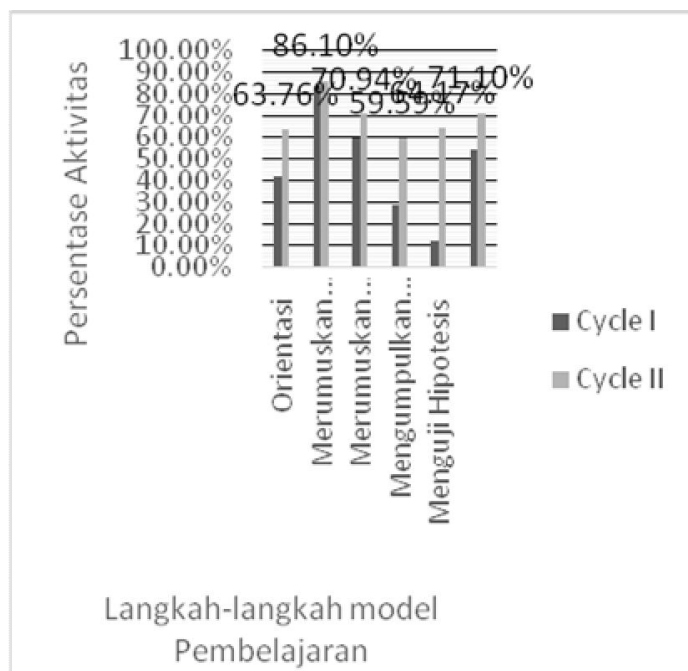

Gambar 1. Grafik Aktivitas Belajar Siswa $\begin{array}{llllll}\text { Kelas } & \text { XI } & \mathrm{IPA}_{3} & \text { SMA } & \text { Negeri } & 7\end{array}$ PinrangSetiap Fase Pembelajaran.

Aktivitas yang diamati pada tiap fase dikelompokkan ke dalam beberapa kelompok indikator aktivitas yaitu visual, oral, listening, dan writing. Persentase rata-rata aktivitas belajar siswa berdasarkan indikator keberhasilan pada siklus II yaitu $71.47 \%$ berada pada kategori aktif dapat dilihat pada tabel berikut:

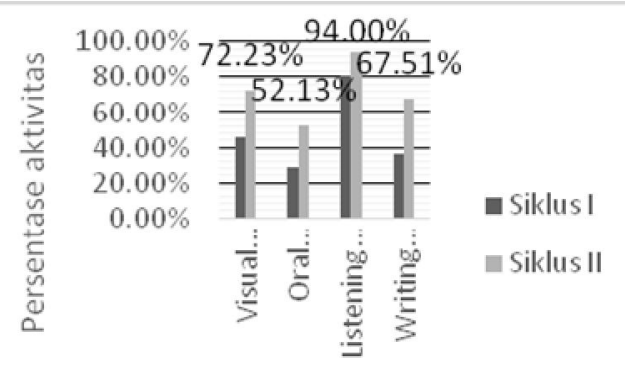

$$
\begin{aligned}
& \text { Berdasarkan Indikator Keberhasilan }
\end{aligned}
$$

Gambar 2. Grafik Aktivitas Belajar Siswa Kelas XI IPA 3 SMA Negeri 7 Pinrang berdasarkan indikator keberhasilan Aktivitas

2) Keterlaksanaan Pembelajaran Inkuiri Terbimbing

Kontekstual

Persentase Berpendekatan pembelajaran siklus II yaitu $100 \%$. Persentase keterlaksanaan pembelajaran 
siklus I dan siklus II ditunjukkan oleh grafik berikut.

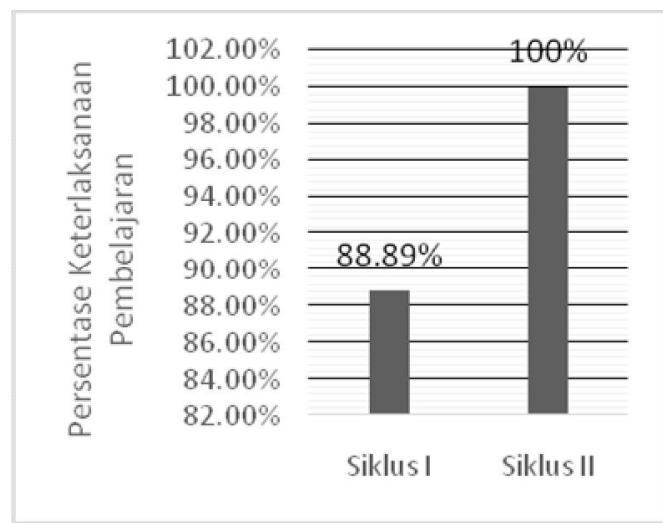

Gambar 3. Grafik Hasil Observasi Keterlaksanaan Pembelajaran

\section{3) Hasil Tes Akhir Siklus II}

Peningkatan hasil tes akhir belajar siklus I ke siklus II ditunjukkan oleh grafik ketuntasan kelas berikut.

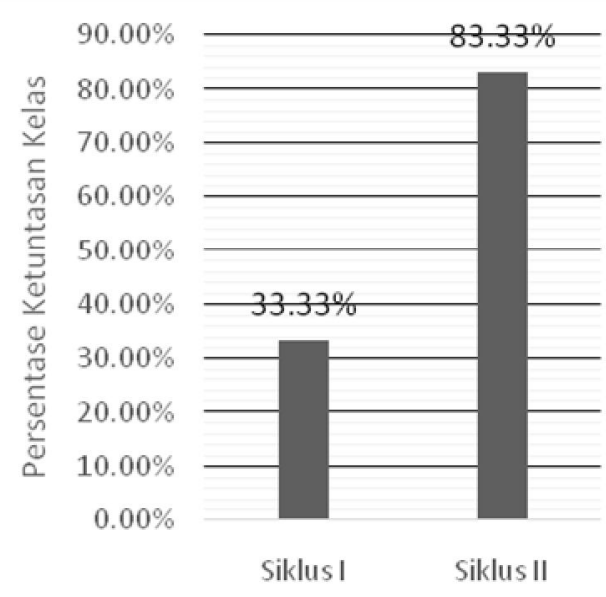

Gambar 4. Grafik Peningkatan Persentase Ketuntasan Kelas XI IPA 3 SMA Negeri 7 Pinrang

\section{4) Catatan Lapangan}

Pada siklus II pembelajaran berlangsung selama dua kali pertemuan. Kekurangan yang terdapat selama pembelajaran di siklus II sudah diperbaiki setelah melihat hasil pengamatan observer pada siklus I.

\section{Refleksi siklus II}

Persentase rata-rata aktivitas belajar siswa berdasarkan indikator keberhasilan pada siklus II dalam penelitian ini telah berada pada kategori aktif yaitu $71.47 \%$ yang sebelumnya $47.75 \%$.Persentase keterlaksanaan pembelajaran pada siklus II juga telah meningkat dari $88.89 \%$ menjadi $100 \%$. Hasil ini juga berbanding lurus dengan meningkatnya ketuntasan kelas dalam tes akhir belajar dari siklus I $33.33 \%$ menjadi $83.33 \%$ pada siklus II. Berdasarkan indikator keberhasilan yang menyatakan bahwa persentase rata-rata aktivitas belajar $\geq 65 \%$ dan hasil belajar berada pada ketuntasan kelas $80 \%$ telah tercapai sehingga dapat dikatakan penelitian ini berhasil dan diberhentikan pada siklus II.

\section{B. Pembahasan}

Model pembelajaran inkuiri terbimbing berpendekatan kontekstualdapat meningkatkan aktivitas belajar siswa. Hal tersebut dapat dilihat dari aspek-aspek aktivitas yang diamati dari siklus I yang sampai siklus II. Model pembelajaran inkuiri terbimbing berpendekatan kontekstual terdiri dari enam fase pembelajaran.

Pertama fase orientasi adalah fase untuk membina suasana atau iklim pembelajaran yang responsif. Ada tiga item aktivitas berdasarkan indikator keberhasilan pada fase ini yaitu listening activity, oral activity dan writing activity. Item pertama, persentase siswa yang berani mengacungkan tangan untuk menjawab pertanyaan guru pada saat menyampaikan apersepsi yaitu $16.11 \%$. Rendahnya persentase ini karena siswa berani menjawab jika secara bersamaan tanpa mengancungkan tangan, tetapi jika diminta suasana tiba-tiba menjadi hening. Hal ini disebabkan oleh ketidakberanian siswa mengeluarkan pendapatnya dengan alasan takut salah.Guru memotivasi siswa dan membuat suasana pembelajaran lebih santai serta merasa akrab dengan siswa. Misalnya, ketika menjelaskan sesuatu, guru menggunakan bahasa sederhana yang tidak terlalu formal kadang melempar senyum dan candaan kepada siswa. Selain itu, guru mendekati tempat duduk siswa selama pembelajaran. Tindakan yang dilakukan guru ternyata dapat meningkatkan aktivitas belajar siswa pada aspek tersebut menjadi $31.67 \%$. Kemudian item kedua, saat guru 
menyampaikan motivasi, ada $11.11 \%$ Setelah memberikan tindakan tersebut persentasi aktivitas siswa meningkat di siklus II menjadi $26.67 \%$.

Fase merumuskan masalah adalah fase dimana siswa dihadapkan pada suatu persoalan yang membuat mereka berpikir dengan mencari penyelesaian untuk menemukan jawaban yang tepat. Aktivitas berdasarkan indikator keberhasilan yang muncul pada fase ini yaitu listening activity, visual activity dan oral activity. Persentase siswa yang melakukan aktivitas yang diamati di semua aspek pada fase ini sudah berada pada kategori aktif.

Fase merumuskan hipotesis adalah fase di mana siswa merumuskan dugaan sementara atau hipotesis atas permasalahan yang telah diberikan oleh guru. Ada satu item yang persentase aktvitasnya masih berada pada kategori tidak aktif saat siswa disuruh mengajukan hipotesis (oral activity) hanya ada 10.00 $\%$. Padahal sudah ada pembagian kelompok dan hanya masing-masing satu orang perwakilan dari tiga kelompok yang mengacungkan tangan untuk mengajukan hipotesis. Tindakan yang diberikan adalah memberikan topik tambahan yang bersifat kontekstual pada rumusan masalah supaya siswa lebih tertarik dan mudah menyelesaikannya. Kemudian memberikan poin bagi kelompok yang anggotanya aktif mengacungkan tangan menyampaikan hipotesis bukan hanya ketua kelompok karena keaktifan anggota dalam kelompok menentukan nilai kelompok. Pemberian tindakan ini meningkatkan persentase siswa yang melakukan aktivitas belajar pada siklus II menjadi $32.83 \%$.

Fase mengumpulkan data adalah aktivitas mencari informasi yang dibutuhkan siswa untuk menguji hipotesis yang telah diajukan. Guru melakukan proses tanya-jawab dengan siswa untuk penemuan informasi. Ada dua item aktivitas pada fase ini item pertama termasuk dalam visual activity dan item kedua termasuk oral activity. Persentase kedua aktivitas ini masih berada pada kategori kurang aktif. Siswa membaca buku atau sumber lain sebagai penunjang dalam pembelajaran yang tergolong visual activity persentase aktivitasnya hanya $35.56 \%$.Guru menugaskan setiap kelompok untuk membawa minimal tiga buku pelajaran, bagi kelompok yang tidak memenuhi mendapat sanksi berupa pengurangan poin. Ternyata ada peningkatan persentase siswa yang melakukan aktivitas setelah memberikan tindakan tersebut menjadi $61.67 \%$. Persentase ini sudah mencapai kategori cukup aktif

Pada oral activity, $51.67 \%$ siswa melakukan diskusi untuk menyelesaikan kegiatan siswa dalam LKS. Pada saat ditanya mengenai hasil pekerjaannya siswa tersebut hanya diam. Oleh sebab itu, guru menghampiri setiap kelompok untuk mengecek pekerjaannya dan bertanya kepada siswa yang kurang aktif. Guru juga menyampaikan kepada ketua kelompok untuk membagi tugas kepada setiap anggota kelompok agar mereka memiliki tanggungjawab masing-masing. Persentase aktivitas siswa meningkat pada aspek tersebut setelah diberikan tindakan menjadi $83.33 \%$ pada siklus II sudah mencapai kategori aktif. Persentase kenaikan aktivitas siswa pada item ini sebesar $31.66 \%$.

Fase menguji hipotesis adalah penentuan mengenai ketepatan hipotesis yang diajukan siswa dengan informasi yang telah diperoleh. Ada empat item aktivitas dan aktivitas berdasarkan indikator keberhasilan yang terdapat yang terdapat pada fase ini yaitu writing activity dan oral activity. Persentase siswa di semua item aktivitas pada fase ini belum mencapai kategori aktif. Item pertama, siswa menggunakan sumber lain yang dapat membantunya menguji hipotesis namun pada aspek ini hanya $18.89 \%$. Oleh karena itu, guru menugaskan siswa untuk membawa referensi berupa artikel atau jurnal terkait sub pokok materi yang dipelajari. Setelah diberikan tindakan tersebut, persentase aktivitas siswa meningkat menjadi $58.34 \%$ siswa pada siklus. Pada writing activity hanya $10.00 \%$ siswa yang berani mengacungkan tangan untuk mengerjakan soal di papan tulis. Sehingga guru 
memotivasi siswa agar lebih berani menunjukkan hasil pekerjaanya di papan tulis. Kemudian menjelaskan bagian yang tidak dipahami oleh siswa dan menyuruh siswa yang telah paham untuk mengajari temannya yang belum paham.

Setelahdiberikan tindakan, persentase siswa yang melakukan aktivitas pada aspek ini meningkat menjadi $35.00 \%$. Item kedua, siswa yang mencocokkan hipotesis kelompoknya dengan sumber dan data yang diperoleh hanya $15.55 \%$ siswa. Oleh karena itu, guru mengatakan hal ini penting dilakukan untuk mengetahui bagian yang keliru. Kemudian guru menghampiri setiap kelompok untuk menyuruh siswa menulis hipotesis yang benar. Setelah memberikan tindakan, persentasenya meningkat sebesar $71.67 \%$ siswa. Kenaikan persentase siswa yang melakukan aktivitas pada item tersebut sebesar 56.12\%. Item berikutnya, persentase siswa yang menyampaikan tanggapan sendiri untuk mempertahankan hipotesis, oral activity hanya $7.78 \%$ siswa. Tindakan yang diberikan adalah menyampaikan kepada siswa bahwa tidak perlu ragu-ragu untuk berpendapat karena ini merupakan suatu pembelajaran yang melatih kalian berbicara di depan umum karena jangan sampai pendapat kalian yang benar dan guru yang keliru. Setelah memberikan tindakan, persentasenya meningkat sebesar $56.67 \%$ pada siklus II sudah mencapai kategori cukup aktif.

Fase merumuskan kesimpulan adalah fase dimana siswa mendeskripsikan temuan (konsep) yang diperoleh berdasarkan hasil pengujian hipotesis. Ada tiga item aktivitas pada fase ini dua diantaranya termasuk listening activity dan salah satunya oral activity. Ada satu item pada fase ini yang persentasenya belum mencapai kategori aktif yaitu siswa yang mengacungkan tangan untuk menyampaikan kesimpulan materi yang telah dipelajari (oral activity) hanya $12.22 \%$.Memberikan kesempatan bagi setiap siswamenyampaikan kesimpulan materi yang telah dipelajari untuk mengetahui sejauh mana pemahamannya terhadap materi yang telah dipelajari. Selain itu, guru menunjuk langsung siswa yang masih malu-malu untuk acungkan tangan. Setelah memberikan tindakan ini persentasenya menjadi $26.67 \%$.

Persentase

keterlaksanaan pembelajaran yang dilakukan guru pada siklus I hanya $88.89 \%$. Pada siklus II persentase keterlaksanaan pembelajaran yang dilakukan guru sudah meningkat menjadi $100 \%$. Hasil belajar diukur dengan memberikan tes berupa soal uraian di setiap akhir siklus. Pada siklus I hasil rata-rata hasil tes akhir siklus I yaitu 60.81 dengan persentase ketuntasan kelas $33.33 \%$ pada yang terdiri dari sub pokok materi kemolaran, konsep laju reaksi dan faktor-faktor yang mempengaruhi laju reaksi. Persentase ini berada pada kategori kurang, terlihat pada persentase aktivitas siswa di setiap langkah-langkah pembelajaran. Persentase aktivitas dan hasil belajar pada siklus I belum mencapai kategori aktif. Faktor yang menyebabkan hal tersebut yaitu 1) persentase keterlaksanaan pembelajaran dengan model inkuiri berpendekatan kontekstual belum mencapai $100 \%$ artinya ada item-item pada langkahlangkah pembelajaran yang tidak dilakukan oleh guru. 2) Siswa masih menyesuaikan diri untuk diajar dengan model ini sehingga alokasi waktu yang digunakan kurang sesuai RPP.

Setelah melakukan refleksi terhadap hasil yang diperoleh pada siklus I kemudian memberikan tindakan pada langkah-langkah model pembelajaran persentase hasil belajar siswa meningkat menjadi 83.08 dengan ketuntasan kelas $83.33 \%$.

Uraian di atas menunjukkan bahwa penerapan langkah-langkah model inkuiri terbimbing melalui pendekatan kontekstualmeningkatkan aktivitas belajar siswa dari siklus I ke siklus II. Hasil ini relevan dengan meningkatnya hasil belajar. Sehingga dapat dinyatakan bahwa melalui langkah-langkah dalam setiap fase model pembelajaran inkuiri terbimbing melalui pendekatan kontekstual dapat meningkatkan aktivitas dan hasil belajar belajar siswa kelas XI $\mathrm{IPA}_{3}$ SMA Negeri 7 Pinrang yang menjadi latar belakang masalah dalam 
penelitian ini. Hasil ini sesuai dengan hasil penelitian yangtelah dilakukan olehZahara (2011) bahwa pembelajaran inkuiri terbimbing melalui pendekatan kontekstual meningkatkan hasil belajar siswa.

\section{KESIMPULAN DAN SARAN}

\section{A. Kesimpulan}

Berdasarkan penelitian yang telah dilakukan maka dapat disimpulkan bahwa langkah-langkah model pembelajaran inkuiri berpendekatan kontekstual dapat meningkatkan aktivitas dan hasil belajar siswa SMAN 7 Pinrang sebagai berikut:

a.Fase orientasi dilakukan dengan memotivasi siswa agar berani menyampaikan pendapatnya. Guru membuat suasana pembelajaran lebih santai serta merasa akrab dengan siswa dan menghampiri tempat duduk siswa.

b.Fase merumuskan masalah dilakukan dengan memberikan sebuah permasalahan kontekstual yang terdapat pada LKS.

c. Fase merumuskan hipotesis dilakukan dengan memberikan tambahan topik yang bersifat kontekstual pada rumusan masalah supaya siswa lebih tertarik dan mudah menyelesaikannya.Selain itu, memberikan poin bagi kelompok yang anggotanya berani mengacungkan tangan untuk berhipotesis.

d.Fase mengumpulkan data dilakukan dengan memberikan tugas kepada siswa membawa buku pegangan untuk membantu kita mencari informasi tambahan. Kemudian menginformasikan bahwa dalam satu kelompok minimal ada tiga buku pelajaran bagi kelompok yang tidak memenuhi mendapat pengurangan poindan menghampiri setiap kelompok untuk mengecek pekerjaannya dan mengamati langsung kinerja siswa.

e. Fase menguji hipotesis dilakukan dengan memberikan tugas kepada siswa membawa sumber lain seperti artikel atau jurnal. Kemudian menyuruh siswa yang telah paham untuk membantu memahamkan temannya selanjutnya menunjuk mereka secara acak. Menyampaikan kepada siswa agar mencocokkan hipotesisnya sehingga diketahui bagian yang keliru dari hipotesisnya.

f. Fase merumuskan kesimpulan dilakukan dengan memberikan kesempatan kepada siswa bahwa siapapun bisa menyampaikan kesimpulan materi yang telah dipelajari untuk mengetahui sejauh mana pemahaman kalian terhadap materi yang telah dipelajari.

\section{B. Saran}

Adapun saran yang dapat disampaikan oleh peneliti setelah melakukan penelitian yaitu sebagai berikut:

1. Model pembelajaran inkuiri terbimbing melalui pendekatan kontekstual dapat dijadikan sebagai salah satu alternatif untuk meningkatkan aktivitas dan hasil belajar siswa yang memiliki karakter yang sesuai dengan model tersebut.

2. Bagi peneliti selajutnya sebaiknya memperhatikan kesiapan, dan ketersediaan sumber belajar siswa sebelum hari pelaksanaan pembelajaran dimulai untuk mendukung berlangsungnya pembelajaran yang efektif.

\section{DAFTAR PUSTAKA}

Rusman. $2010 . \quad$ Model-Model Pembelajaran. Bandung: PT Rajagrafindo Persada.

Sanjaya, Wina. 2006. Strategi Pembelajaran Berorientasi Standar Proses Pendidikan. Jakarta: Pranada Media Grup.

Masita, Meici, Edwin Musdi dan Muhammad Subhan. 2012. Peningkatan aktivitas siswa pada pembelajaran matematika melalui pendekatan kontekstual. Jurnal Pendidikan Matematika. 1 (2), 23.

Mahmud. 2011. Metode Penelitian Pendidikan. Bandung: CV PUSTAKA SETIA.

Wahyudi, Lutfi Eko dan Supardi Imam. 2013. Penerapan Model Pembelajaran Inkuiri Terbimbing Pada Pokok Bahasan Kalor Untuk Melatihkan Keterampilan Proses Sains Terhadap Hasil Belajar Di Sman 1 Sumenep. 
Jurnal Inovasi Pendidikan Fisika. 2 (2), 2.

Manang, Riatun S dan Laliyo Lukman AR. 2012. Pengaruh Pendekatan Pembelajaran Kontekstual Terhadap Hasil Belajar Siswa Pada Materi Laju Reaksi di SMA Negeri 1 Gorontalo. Gorontalo: Pendidikan Kimia, Fakultas MIPA Universitas Negeri Gorontalo. 